\title{
Inhibitory effects of ethanolic extract of two Iranian pomegranates peel cultivars on Staphylococcus aureus and Salmonella typhimurium
}

\begin{abstract}
Marzieh Tadi $^{1}$, Hamdollah Moshtaghi Boroujeni' ${ }^{1}$ Mahmoud Rafieian-kopaei ${ }^{2}$, Elham Khalili Sadrabad ${ }^{3 *}$
${ }^{1}$ Department of Food Hygiene, Faculty of Veterinary Medicine, Shahrekord University, Shahrekord, Iran

${ }^{2}$ Department of Pharmacology, Shahrekord University of Medical Sciences, Shahrekord, Iran

${ }^{3}$ Zoonotic Diseases Research Center, Department of Food Safety and Hygiene, School of Public Health, Yazd Shahid Sadoughi University of Medical Sciences, Yazd, Iran

Abstract

In last decades, the antibiotic resistance is considered one of the essential problems. Therefore, uses of waste agricultural products such as pomegranate peel have drawn attention to be used as an effective preservative in food industry. Ethanolic extract of pomegranate peels (Naderi and Mallas) were prepared. Then, the antibacterial effects on two foodborne pathogens (Staphylococcus aureus and Salmonella typhimurium) in meat broth and TSB media at two temperatures levels $\left(4{ }^{\circ} \mathrm{C}\right.$ and $\left.15^{\circ} \mathrm{C}\right)$ during storage were investigated. The Minimal Inhibitory Concentration (MIC) values of Naderi and Mallas cultivar for Staphylococcus aureus and Salmonella typhimurium were measured 15.62 and $62.5 \mathrm{mg} / \mathrm{ml}$, and 19.5 and $64.5 \mathrm{mg} / \mathrm{ml}$ respectively. The Minimum Bactericidal Concentration (MBC) of Naderi and Mallas cultivar were evaluated 125 and $130 \mathrm{mg} / \mathrm{ml}$ for both bacteria. All concentration of Mallas and Naderi Pomegranate Peel Extract (PPE) in meat broth at $4{ }^{\circ} \mathrm{C}$ and $15^{\circ} \mathrm{C}$ inhibited Staphylococcus aureus growth. It was reported that PPE was less effective in decreasing the $S$. typhimurium growth compared to the $S$. aureus. Naderi cultivar showed better effects on bacterial inhibition in compared to Mallas cultivar. According to achieved results, it could be suggested to use the ethanolic extract of pomegranate peel as a useful preservative against foodborne bacteria in the food processing industry.
\end{abstract}

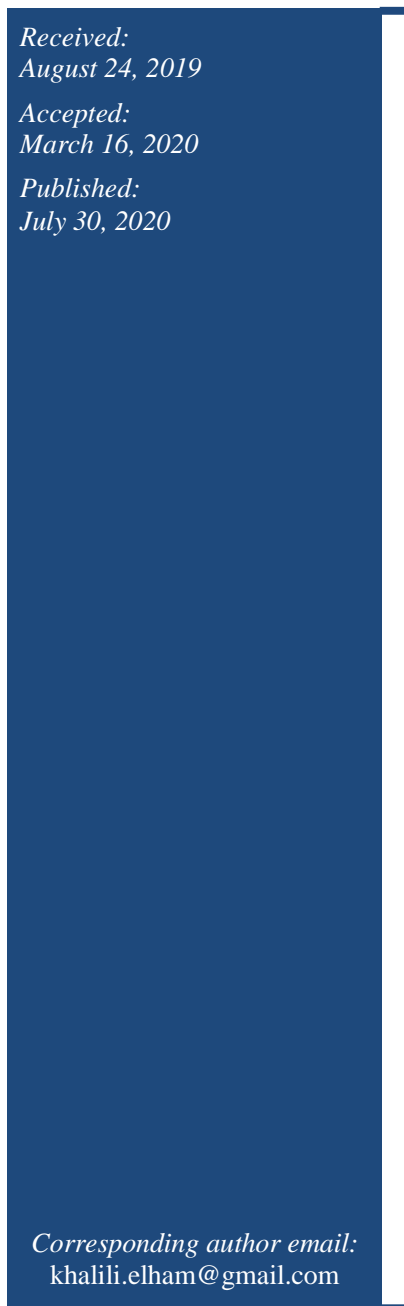

Keywords: Pomegranates peel, Naderi cultivar, Mallas cultivar, Staphylococcus aureus, Salmonella typhimurium

\section{How to cite this:}

Tadi M, Boroujeni HM, Rafieian-kopaei M and Sadrabad EK, 2020. Inhibitory effects of ethanolic extract of two Iranian pomegranates peel cultivars on Staphylococcus aureus and Salmonella typhimurium. Asian J. Agric. Biol. 8(3): 341-347. DOI: https://doi.org/10.35495/ajab.2019.07.318

This is an Open Access article distributed under the terms of the Creative Commons Attribution 3.0 License. (https://creativecommons.org/licenses/by/3.0), which permits unrestricted use, distribution, and reproduction in any medium, provided the original work is properly cited.

\section{Introduction}

The Infectious disease is known as the one of the major causes of death in the world. During last decades, by increasing concerns about antibiotic resistance the uses of natural and conventional products as a preventive agent for bacterial disease have gained much attention. Therefore, many studies 
on antimicrobial activities of herbal medicines have been reported (Amirmohammadi et al., 2014; AsadiSamani et al., 2014; Bahmani et al., 2014). The presence of antibacterial compounds in plants could have preventive role in the growth of pathogens. Pomegranate (Punica granatum L.) is the oldest functional fruits cultivated in Iran and neighboring countries (Gullon et al., 2016). Pomegranate peel is a waste part of the juice industry which compromise about $50 \%$ of the total weight of pomegranate fruit (Fawole et al., 2012). The pomegranate peel is rich in bioactive compounds such as ellagic tannins, flavonols, anthocyanins, catechin, procyanidins, ellagic acid and gallic acid (Fawole et al., 2012; Gullon et al., 2016). These constitute differs from one cultivar to another as well as climate changes, and place of growth (Fawole et al., 2012). It was shown that all parts of pomegranate fruit are useful for the treatment of common diseases (Ross et al., 2001). Presence of tannins and other biochemical compounds such as phenolic compounds in pomegranate fruit introduced this fruit as an antibacterial, antiviral, antioxidant, and antiinflammatory bioactive agent (Fawole et al., 2012; Malviya et al., 2014). Although the pomegranate peel is considered to be effective enough to be used without any enrichments. It was reported that phenolics compounds in pomegranate peel are involved in bacterial cell lysis by precipitation of membrane proteins and inhibition of enzymatic activities (such as glycosyltransferases) (Ismail et al., 2012).

Due to various medical effects of pomegranate and its different parts, it could be helpful to investigate the antibacterial effects of its extracts. However, there is a need to examine the inhibitory effects of different varieties of pomegranates peel extract cultivated in Iran against foodborne pathogens. In current study $S$. aureus and $S$. typhimurium were chosen because of their outbreaks and emergence of drug resistance strains (Gullon et al., 2016). By knowing the efficacy of antibacterial activity of pomegranate peel extract (PPE), the use of its extract in food industry as natural food additives could be proven. Therefore, the objective of the present study was the investigation of antibacterial effects of pomegranate peel extract of two cultivar (Naderi and Mallas cultivated in Iran) against Staphylococcus aureus and Salmonella typhimurium in red meat extract and TSB at two temperatures $\left(4{ }^{\circ} \mathrm{C}\right.$ and 15 $\left.{ }^{\circ} \mathrm{C}\right)$. Also, the differences in antibacterial activities of two pomegranate cultivars (Naderi and Mallas) were studied.

\section{Material and Methods}

\section{Pomegranate fruit and preparation of extract}

Two cultivars of Naderi and Mallas pomegranate fruits were purchased from local market of Iran. The fresh fruits were cleaned, peeled manually, dried in an incubator $\left(30-40{ }^{\circ} \mathrm{C}\right)$, and milled. One gram of powdered pomegranate peel was dissolved in $10 \mathrm{ml}$ aqueous ethanol $(80 \%)$ and placed in a shaker for 24 hours at room temperature. Then extracts were filtered and dried in oven at $37^{\circ} \mathrm{C}$. The crude extract was stored at $4{ }^{\circ} \mathrm{C}$ until use (Derakhshan et al., 2018).

\section{Methods of red meat extraction}

Fresh beef were purchased from the market and transferred immediately to the laboratory under suitable condition. The meat broth was prepared by mixing the ground meat and homogenizing in distilled water at a ratio of 1 to 10 by stomacher. In order to coagulate the proteins, homogenized samples were cooked and the resulting broth was passed through filter and, then sterilized by autoclave at 121 ${ }^{\circ} \mathrm{C}$ for $15 \mathrm{~min}$.

\section{Microorganisms}

The Staphylococcus aureus (PTCC 1113) and Salmonella typhimurium (RTCC 1735) were obtained from the Persian Type Culture Collection (PTCC) and the Razi Vaccine and Serum Research Institute (RTCC), Tehran, Iran, respectively. The bacterial strains were cultured on Tryptic Soy Broth (TSB, Merck, Germany) at $37{ }^{\circ} \mathrm{C}$ for $20 \mathrm{~min}$ and $0.5 \mathrm{Mc}$ Farland dilutions were prepared (Abdollahzadeh et al., 2011).

\section{Determination of antibacterial activity}

Separate tubes containing $1 \mathrm{ml}$ of red meat extract and $1 \mathrm{ml}$ of TSB were prepared for each bacterium. The amount of $10 \mathrm{ml}$ of bacterial suspension was added to each test tube to reach the concentration of $10^{7}$ colony forming units (CFU). Thereafter, pomegranate extract was added to reach the dilutions of $0.5 \%, 1 \%, 2.5 \%$, and $5 \%$. One tube of meat extract and one tube of TSB without pomegranate addition were considered as controls. All tested groups were incubated at $4^{\circ} \mathrm{C}$ and $15^{\circ} \mathrm{C}$ temperatures. The bacterial count was done at $0,1,3,6,24$ and 48 hours after incubation. Then, the samples were cultured on 
Tryptic Soy Agar (TSA, Merck, Germany) and incubated at $37{ }^{\circ} \mathrm{C}$ for 24 hours (Boniadian et al., 2014).

\section{Minimum inhibition concentration (MIC) and Minimum bactericidal concentration (MBC) assays}

The MIC of the pomegranate extract was determined using macro dilution technique wherein the extract was diluted serially in a series of ten test tubes containing TSB $(0.5 \mathrm{ml})$ and all tubes were loaded with $0.5 \mathrm{ml}$ of each bacterium $\left(10^{6} \mathrm{CFU} / \mathrm{ml}\right)$ and then incubated at $37{ }^{\circ} \mathrm{C}$ for $24 \mathrm{~h}$. The first tube with transparent appearance was considered as a MIC. All analysis was done in triplicate (Boniadian et al., 2014). The transparent tubes were cultured on Muller Hinton agar plates and after $24 \mathrm{~h}$ incubation $\left(37{ }^{\circ} \mathrm{C}\right)$ and the tubes with no bacterial growth recorded as MBC (Naziri et al., 2012).

\section{Statistical analysis}

Statistical analyses of the results were carried out using SPSS and the bacterial count was analyzed by a one way ANOVA and LSD comparison test.

\section{Results and Discussion}

\section{Minimum Inhibition Concentration and Minimum Bactericidal Concentration}

The pomegranate extracts minimum inhibitory concentrations (MIC) and minimum bactericidal concentrations (MBC) are shown in table 1. It was shown that two cultivar of PPE had antibacterial activity against both bacteria. According to AlZoreky (2009) research MIC of S. aureus, was evaluated $2 \mathrm{mg} / \mathrm{ml}$ which was estimated lower than results of current study. The MIC of $S$. aureus in active pomegranate extract was reported 40 and 90 $\mu \mathrm{g} / \mathrm{ml}$ by Duman et al. (2009). In Hayouni et al. (2011) study $S$. typhimurium was considered the second most sensitive microorganism to methanolic extract of pomegranate peel with the MIC of 0.25 $\mathrm{mg} / \mathrm{ml}$, which is not in agreement with present study. Fawole et al. (2012) showed the MIC value of Methanolic extract of pomegranate ranges from 0.2 to $0.78 \mathrm{mg} / \mathrm{ml}$. By comparing results of present study with these reports, the MIC values achieved in current research are considerably higher than previous studies. The MIC and MBC values of 50 and $60 \mathrm{mg} / \mathrm{ml}$ against Salmonella $s p$ and $S$. aureus were reported by Gullon et al. (2016). The MBC of present research was evaluated 125 and $130 \mathrm{mg} / \mathrm{ml}$ for Naderi and Mallas PPE respectively which was not in line with Gullon et al. (2016) report. It was shown that the variation in results achieved by different researchers is due to differences among pomegranate cultivars, extraction methods, strain sensitivity, and antibacterial procedures (Gullon et al., 2016). According to our result MIC value of two investigated cultivars were varied, which is due to inter-genetic cultivar variability, geo-environmental spatial variation, and chemical heterogeneity (Fawole et al., 2012).

Table-1. Minimum inhibitory concentrations (MIC) and minimum bactericidal concentrations (MBC) $(\mathrm{mg} / \mathrm{mL})$ of pomegranate ethanolic extract

\begin{tabular}{|c|c|c|c|}
\hline $\begin{array}{c}\text { Pomegranate } \\
\text { cultivar }\end{array}$ & Bacterium & MIC & MBC \\
\hline \multirow{2}{*}{ Naderi } & Staphylococcus aureus & 15.62 & 125 \\
\cline { 2 - 4 } & Salmonella typhimurium & 62.5 & 125 \\
\hline \multirow{2}{*}{ Mallas } & Staphylococcus aureus & 19.5 & 130 \\
\cline { 2 - 4 } & Salmonella typhimurium & 64.75 & 130 \\
\hline
\end{tabular}

\section{Antibacterial effect of PPE in meat broth}

In different studies, various degrees of bacterial growth inhibition were reported by using PPE. Because of the importance of $S$. aureus and $S$. typhimurium in food poisoning of Iran, their sensitivity to PPE in meat broth and TSB media at 4 ${ }^{\circ} \mathrm{C}$ and $15^{\circ} \mathrm{C}$ were investigated.

Results of bacterial growth in different concentration of PPE at $4{ }^{\circ} \mathrm{C}$ and $15^{\circ} \mathrm{C}$ were shown in Table 2 to 5 . It was shown the $S$. aureus inhibition by Naderi PPE in all concentration at $4{ }^{\circ} \mathrm{C}$ and $1 \%, 2.5 \%$ and $5 \%$ concentrations at $15{ }^{\circ} \mathrm{C}$. Otherwise, all concentrations of Mallas PPE were significantly effective in reduction of $S$. aureus in meat broth at both temperatures.

The reduction in initial population of $S$. typhimurium in meat broth samples treated by Naderi PPE at $4{ }^{\circ} \mathrm{C}$ were recorded at $0.5 \%$ and $1 \%$ concentrations and $2.5 \%$ and $5 \%$ concentrations in 6 and 3 hours of storage, respectively. Results of current study manifested that by increasing in the concentration of Naderi PPE, the antibacterial activity at $15{ }^{\circ} \mathrm{C}$ and 4 ${ }^{\circ} \mathrm{C}$ was increased.

It could be concluded that the sensitivity of $S$. aureus to Naderi PPE was more pronounced at $15^{\circ} \mathrm{C}$ compared to $4^{\circ} \mathrm{C}$. The achieved result indicated the better function of Naderi PPE in inhibiting S. aureus 
growth than Mallas one. This could be attributed to antibacterial compounds in pomegranates peel such as phenols, flavonoids and tannins (Al-Zoreky, 2009) and lower $\mathrm{pH}$ of Naderi PPE. The inhibitory effect of Mallas PPE on S. typhimurium in meat broth was obtained at $2.5 \%$ and $5 \%$ concentrations at $4{ }^{\circ} \mathrm{C}$ by the end of storage time, which was significantly reduced by $1.5 \operatorname{logs}$ at $5 \%$ concentration. On the other hand, the reduction in S. typhimurium growth at $0.5 \%$ and $1 \%$ levels was only shown until the first hour of storage. The bacteriostatic activity of Mallas PPE against $S$. typhimurium at $15{ }^{\circ} \mathrm{C}$ was reported in 1,3 and 6 hours of storage. It could be suggested that $2.5 \%$ and $5 \%$ PPE inhibit S. typhimurium at $4{ }^{\circ} \mathrm{C}$ better than $15{ }^{\circ} \mathrm{C}$.

PPE was less effective in inhibiting the $S$. typhimurium compared to the $S$. aureus. The existence of outer phospholipidic membrane in Gram negative bacteria had been resulted in higher resistance to different treatments (Djenane et al., 2011). Moreover, hydrophobic constituents in extracts and essential oils increase the ion permeability and leakage of intracellular component of Gram positive bacteria (Djenane et al., 2011). Ahmad and Beg (2001) reported antibacterial activity of alcohol extracts of pomegranate against $S$. aureus, Escherichia coli and Shigella dysenteriae. Opara et al. (2009) determined the antimicrobial activity against $S$. aureus in all studied varieties of pomegranates. Overall, the current findings approved the results achieved by Negi and Jayaprakasha (2003) which was investigated the ethyl acetate, acetone, methanol extract of pomegranate peel. They indicated a high inhibition activity on both Gram-positive and Gram-negative bacteria such as S.aureus, Pseudomonas aeruginosa, and B. aurous, although E.coli had been resistance to extract (Negi and Jayaprakasha, 2003). Al-Zoreky (2009) reported inhibition effect of methanolic extract of pomegranate peel against $S$. aureus, Listeria monocytogenes, E. Coli and Yersinia enterocolitica. Hayrapetyan et al. (2012) studied the effect of pomegranate peel extract in meat pate and it was shown that $S$. aureus had the highest sensitivity among Bacillus cereus, E. Coli, B. subtilis and L. monocytogenes.

Table-2. Bacterial count $(\log , \mathrm{CFU} / \mathrm{ml})$ in different concentrations of Naderi PPE in meat broth at $4{ }^{\circ} \mathrm{C}$ and $15{ }^{\circ} \mathrm{C}$

\begin{tabular}{|c|c|c|c|c|c|c|c|}
\hline Bacteria & Temperature & $\begin{array}{c}\text { Time } \\
\text { (h) }\end{array}$ & \multicolumn{5}{|c|}{$\begin{array}{c}\text { Naderi PPE concentrations } \\
(\text { Mean } \pm \text { SD) }\end{array}$} \\
\hline & \multirow{5}{*}{$4^{\circ} \mathrm{C}$} & & control & $0.5 \%$ & $1 \%$ & $2.5 \%$ & $5 \%$ \\
\hline \multirow{2}{*}{$\begin{array}{l}\text { Staphylococcus } \\
\text { aureus }\end{array}$} & & 0 & 6.3 & 6.3 & 6.3 & 6.3 & 6.3 \\
\hline & & 48 & $6.01 \pm 0.31$ & $5.02 \pm 0.37$ & $4.57 \pm 0.51$ & $4.64 \pm 0.67$ & $3.84 \pm 0.59$ \\
\hline \multirow{2}{*}{$\begin{array}{l}\text { Salmonella } \\
\text { typhimurium }\end{array}$} & & 0 & 6.3 & 6.3 & 6.3 & 6.3 & 6.3 \\
\hline & & 48 & $6.88 \pm 0.31$ & $6.55 \pm 0.37$ & $6.50 \pm 0.51$ & $6.54 \pm 0.67$ & $6.30 \pm 0.59$ \\
\hline \multirow{2}{*}{$\begin{array}{l}\text { Staphylococcus } \\
\text { aureus }\end{array}$} & \multirow{4}{*}{$15^{\circ} \mathrm{C}$} & 0 & 6.3 & 6.3 & 6.3 & 6.3 & 6.3 \\
\hline & & 48 & $6.32 \pm 0.08$ & $5.90 \pm 0.40$ & $4.91 \pm 0.89$ & $4.32 \pm 0.88$ & $3.26 \pm 1.09$ \\
\hline \multirow{2}{*}{$\begin{array}{l}\text { Salmonella } \\
\text { typhimurium }\end{array}$} & & 0 & 6.3 & 6.3 & 6.3 & 6.3 & 6.3 \\
\hline & & 48 & $8.81 \pm 1.14$ & $7.38 \pm 0.82$ & $7.84 \pm 0.78$ & $7.23 \pm 0.65$ & $6.32 \pm 0.41$ \\
\hline
\end{tabular}

Table-3. Bacterial count (log, CFU/ml) in different concentration of Naderi PPE in TSB at $4{ }^{\circ} \mathrm{C}$ and $15{ }^{\circ} \mathrm{C}$

\begin{tabular}{|c|c|c|c|c|c|c|c|}
\hline \multirow[t]{2}{*}{ Bacteria } & Temperature & $\begin{array}{l}\text { Time } \\
\text { (h) }\end{array}$ & & Nade & $\begin{array}{l}\text { PPE concen } \\
\text { Mean } \pm \text { SD }\end{array}$ & ations & \\
\hline & \multirow{5}{*}{$4^{\circ} \mathrm{C}$} & & control & $0.5 \%$ & $1 \%$ & $2.5 \%$ & $5 \%$ \\
\hline \multirow{2}{*}{$\begin{array}{l}\text { Staphylococcus } \\
\text { aureus }\end{array}$} & & 0 & 6.3 & 6.3 & 6.3 & 6.3 & 6.3 \\
\hline & & 48 & $6.02 \pm 0.64$ & $5.38 \pm 0.68$ & $4.76 \pm 0.69$ & $4.66 \pm 0.75$ & $3.70 \pm 1.03$ \\
\hline \multirow{2}{*}{$\begin{array}{l}\text { Salmonella } \\
\text { typhimurium }\end{array}$} & & 0 & 6.3 & 6.3 & 6.3 & 6.3 & 6.3 \\
\hline & & 48 & 8.792 & 7.491 & 7.064 & 4.984 & 4.132 \\
\hline \multirow{2}{*}{$\begin{array}{l}\text { Staphylococcus } \\
\text { aureus }\end{array}$} & \multirow{4}{*}{$15^{\circ} \mathrm{C}$} & 0 & 6.3 & 6.3 & 6.3 & 6.3 & 6.3 \\
\hline & & 48 & $6.98 \pm 0.67$ & $5.97 \pm 0.43$ & $5.82 \pm 0.82$ & $5.08 \pm 0.23$ & $3 \pm 1.03$ \\
\hline \multirow{2}{*}{$\begin{array}{l}\text { Salmonella } \\
\text { typhimurium }\end{array}$} & & 0 & 6.3 & 6.3 & 6.3 & 6.3 & 6.3 \\
\hline & & 48 & $6.94 \pm 1.13$ & $6.52 \pm 0.56$ & $6.31 \pm 0.80$ & $6.51 \pm 0.47$ & $6.54 \pm 0.80$ \\
\hline
\end{tabular}


Table-4. Bacterial count (log, CFU/ml) in different concentration of Mallas PPE in meat broth at $4{ }^{\circ} \mathrm{C}$ and $15^{\circ} \mathrm{C}$

\begin{tabular}{|l|c|c|c|c|c|c|c|}
\hline \multicolumn{1}{|c|}{ Bacteria } & \multirow{2}{*}{ Temperature } & $\begin{array}{c}\text { Time } \\
(\mathbf{h})\end{array}$ & \multicolumn{5}{c|}{ Mallas PPE concentrations } \\
(Mean \pm SD)
\end{tabular}

Table-5. Bacterial count $(\log , \mathrm{CFU} / \mathrm{ml})$ in different concentration of Mallas PPE in TSB at $4{ }^{\circ} \mathrm{C}$ and $15{ }^{\circ} \mathrm{C}$

\begin{tabular}{|c|c|c|c|c|c|c|c|}
\hline Bacteria & Temperature & $\begin{array}{l}\text { Time } \\
\text { (h) }\end{array}$ & & Malla & $\begin{array}{l}\text { PE conce } \\
\text { Mean } \pm S D\end{array}$ & ations & \\
\hline \multirow{3}{*}{$\begin{array}{l}\text { Staphylococcus } \\
\text { aureus }\end{array}$} & \multirow{5}{*}{$4^{\circ} \mathrm{C}$} & & control & $0.5 \%$ & $1 \%$ & $2.5 \%$ & $5 \%$ \\
\hline & & 0 & 6.3 & 6.3 & 6.3 & 6.3 & 6.3 \\
\hline & & 48 & $6.02 \pm 0.13$ & $5.91 \pm 0.36$ & $5.83 \pm 0.34$ & $4.93 \pm 0.68$ & $4.51 \pm 0.76$ \\
\hline \multirow{2}{*}{$\begin{array}{l}\text { Salmonella } \\
\text { typhimurium }\end{array}$} & & 0 & 6.3 & 6.3 & 6.3 & 6.3 & 6.3 \\
\hline & & 48 & $6.94 \pm 0.30$ & $6.60 \pm 0.18$ & $6.34 \pm 0.22$ & $6.54 \pm 0.23$ & $5.60 \pm 0.52$ \\
\hline \multirow{2}{*}{$\begin{array}{l}\text { Staphylococcus } \\
\text { aureus }\end{array}$} & \multirow{4}{*}{$15^{\circ} \mathrm{C}$} & 0 & 6.3 & 6.3 & 6.3 & 6.3 & 6.3 \\
\hline & & 48 & $7.34 \pm 0.65$ & $5.51 \pm 0.71$ & $4.34 \pm 0.78$ & $3.82 \pm 0.88$ & $2.84 \pm 0.99$ \\
\hline \multirow{2}{*}{$\begin{array}{l}\text { Salmonella } \\
\text { typhimurium }\end{array}$} & & 0 & 6.3 & 6.3 & 6.3 & 6.3 & 6.3 \\
\hline & & 48 & $6.81 \pm 0.83$ & $7.54 \pm 0.45$ & $7.65 \pm 0.66$ & $7.30 \pm 0.81$ & $8.46 \pm 0.68$ \\
\hline
\end{tabular}

\section{Antibacterial effect of PPE in TSB media}

According to results, $S$. aureus reduction was reported in samples treated with Naderi PPE at $4{ }^{\circ} \mathrm{C}$ in all concentrations and at $15{ }^{\circ} \mathrm{C}$ in $2.5 \%$ and $5 \%$ concentrations. However, initial populations of $S$. aureus were decreased in all TSB samples treated by Mallas PPE $(\mathrm{p}<0.05)$ at both $4{ }^{\circ} \mathrm{C}$ and $15^{\circ} \mathrm{C}$.

Naderi PPE with $2.5 \%$ and $5 \%$ concentrations reduced the bacterial growth during 48 hours of storage. The reduction in growth of $S$. typhimurium in TSB media at $4{ }^{\circ} \mathrm{C}$ was reported in 5\% Mallas and $2.5 \%$ and 5\% Naderi PPE, respectively. These bacteriostatic effects were shown more powerful at higher concentrations. During the storage at $15{ }^{\circ} \mathrm{C}$, the inhibition of $S$. typhimurium in TSB media treated by Mallas PPE was shown at the first three hours of storage. In overall, Naderi PPE had better function in reduction of bacterial load. This can attributed to the lower $\mathrm{pH}$ of Naderi PPE (pH: 3) than $\mathrm{pH}$ of Mallas PPE ( $\mathrm{pH}$ : 3.5). The wide difference in bacterial inhibition activity may be related to pomegranate varieties and agro climatology differences (Hayrapetyan et al., 2012; Opara et al., 2009). It was seen that PPE was less effective in inhibiting the $S$. typhimurium compared to the S. aureus. Results of current study are compatible with those of Panichayupakaranant who reported antibacterial activity of pomegranate rind extract against $S$. aureus and resistance of $S$. typhimurium (Panichayupakaranant et al., 2010). The antibacterial compounds in pomegranate peel which cause destruction in cell wall, cytoplasmic membrane and membrane proteins have essential role in bacterial death (Ibrahium, 2010). The inhibitory effect of PPE on S.typhimurium was more pronounced at lower temperatures $\left(4^{\circ} \mathrm{C}\right)$ than higher one $\left(15^{\circ} \mathrm{C}\right)$. The inhibition effect of ethanolic extract was shown at lower temperature for $S$. aureus than for $S$. typhimurium. These differences might be due to differences in cell membrane permeability of bacteria at various temperatures (Wu et al., 2016).

It was shown that PPE in meat broth were more effective than in TSB media which could be attributed to low $\mathrm{pH}$ of meat broth. Djenane et al. (2011) infested the importance of meat $\mathrm{pH}$ on bacterial activity of essential oil, which probably could be referred to extracts. According to their results, by lowering the $\mathrm{pH}$, the hydrophobicity of 
essential oil will be increased and their solubility in lipid phase of bacterial membrane facilitated. The current results are in agreement with Durairaj who reported that by increasing the $\mathrm{pH}$ value, the antibacterial effects decreased (Durairaj et al., 2009). Natural antibacterial agents such as ellagitannins, punicalagin, ellagic acid and gallic acid and also, the ability of phenolic compounds to precipitation of membrane proteins and inhibition of enzymes such as glycosyl transferase, make pomegranate peel as a powerful antibacterial preservative.

\section{Conclusion}

Result of current study, clearly confirmed the effectiveness of pomegranate peel on inhibition of bacterial activity. It was reported that two cultivar of PPE had antibacterial activity against $S$. aureus and S. typhimurium. It was shown that PPE in meat broth were more effective than in TSB media which could be attributed to low $\mathrm{pH}$ of meat broth. In general, it could be concluded the Gram positive bacteria was more sensitive to ethanolic extract of pomegranate peel than Gram negative one. Also, the PPE was less effective in inhibiting the $S$. typhimurium compared to the $S$. aureus, which could be due to their outer lipopolysaccharide (LPS) membranes. Also, the inhibitory effect of PPE on S. typhimurium was more pronounced at lower temperatures $\left(4^{\circ} \mathrm{C}\right)$ than higher one $\left(15^{\circ} \mathrm{C}\right)$. According to achieved results, the antibacterial activity of pomegranate and its use in traditional medicine are proved.

\section{Acknowledgment}

The authors would like to acknowledge from Department of food and quality hygiene, Shahrekord University, Faculty of Veterinary Medicine for their cooperation.

Disclaimer: None.

Conflict of Interest: None.

Source of Funding: None.

\section{References}

Abdollahzadeh S, Mashouf R, Mortazavi $\mathrm{H}$, Moghaddam M, Roozbahani N and Vahedi M, 2011. Antibacterial and antifungal activities of
Punica granatum peel extracts against oral pathogens. J. Dentist. 8: 1.

Ahmad I and Beg AZ, 2001. Antimicrobial and phytochemical studies on 45 Indian medicinal plants against multi-drug resistant human pathogens. J. Ethnopharmacol. 74: 113-23.

Al-Zoreky NS, 2009. Antimicrobial activity of pomegranate (Punica granatum L.) fruit peels. Int. J. Food Microbiol. 134: 244-248.

Amirmohammadi M, Khajoenia S, Bahmani M, Rafieian-Kopaei M, Eftekhari Z and Qorbani M, 2014. In vivo evaluation of antiparasitic effects of Artemisia abrotanum and Salvia officinalis extracts on Syphacia obvelata, Aspiculoris tetrapetra and Hymenolepis nana parasites. Asian Pac. J. Trop. Dis. 4. 4(Suppl 1): S250S254.

Asadi-Samani M, Bahmani M and Rafieian-Kopaei M, 2014. The chemical composition, botanical characteristic and biological activities of Borago officinalis: a review. Asian Pac. J. Trop. Med. 7S1: S22-28.

Bahmani M, Rafieian-Kopaei M, Hassanzadazar H, Saki K, Karamati SA and Delfan B, 2014. review on most important herbal and synthetic antihelmintic drugs. Asian Pac. J. Trop. Med. 7(Suppl 1): S29-S33.

Boniadian M, Khalili Sadrabad E, Askari E and Pourmoghadas M, 2014. Effect of peppermint essential oil on growth and survival of some foodborne pathogenic bacteria. J. Food Hygiene. 4(14): 53-62.

Derakhshan Z, Ferrante M, Tadi M, Ansari F, Heydari A, Hosseini MS, Conti GO and Sadrabad EK, 2018. Antioxidant activity and total phenolic content of ethanolic extract of pomegranate peels, juice and seeds. Food Chem. Toxicol. 114:108-111.

Djenane D, Yanguela J, Montañes L, Djerbal M and Roncales P, 2011. Antimicrobial activity of Pistacia lentiscus and Satureja montana essential oils against Listeria monocytogenes CECT 935 using laboratory media: Efficacy and synergistic potential in minced beef. Food Control. 22: 1046-1053.

Duman AD, Ozgen M, Dayisoylu KS, Erbil N and Durgac C, 2009. Antimicrobial activity of six pomegranate (Punica granatum L.) varieties and their relation to some of their pomological and phytonutrient characteristics. Molecules. 14: 1808-1817. 
Durairaj S, Srinivasan S and Lakshmanaperumalsamy P, 2009. In vitro antibacterial activity and stability of garlic extract at different $\mathrm{pH}$ and temperature. Electronic $\mathrm{J}$. Biol. 5: 5-10.

Fawole OA, Makunga NP and Opara UL, 2012. Antibacterial, antioxidant and tyrosinaseinhibition activities of pomegranate fruit peel methanolic extract. BMC Complement. Altern. Med. 12: 200.

Gullon B, Pintado ME, Perez-Álvarez JA and ViudaMartos M, 2016. Assessment of polyphenolic profile and antibacterial activity of pomegranate peel (Punica granatum) flour obtained from co-product of juice extraction. Food Control. 59: 94-98.

Hayouni E, Miled K, Boubaker S, Bellasfar Z, Abedrabba M, Iwaski $\mathrm{H}$, Oku $\mathrm{H}$, Matsui $\mathrm{T}$, Limam F and Hamdi M, 2011. Hydroalcoholic extract based-ointment from Punica granatum L. peels with enhanced in vivo healing potential on dermal wounds. Phytomed. 18: 976-984.

Hayrapetyan H, Hazeleger WC and Beumer RR, 2012. Inhibition of Listeria monocytogenes by pomegranate (Punica granatum) peel extract in meat paté at different temperatures. Food Control. 23: 66-72.

Ibrahium M, 2010. Efficiency of pomegranate peel extract as antimicrobial, antioxidant and protective agents. World J. Agric. Sci. 6: 338344.

Ismail T, Sestili P and Akhtar S, 2012. Pomegranate peel and fruit extracts: a review of potential antiinflammatory and anti-infective effects. J. Ethnopharmacol. 143: 397-405.

Malviya S, Jha A and Hettiarachchy N, 2014. Antioxidant and antibacterial potential of pomegranate peel extracts. J. Food Sci. Technol. 51: 4132-4137.
Naziri Z, Rajaian H and Firouzi R, 2012. Antibacterial effects of Iranian native sour and sweet pomegranate (Punica granatum) peel extracts against various pathogenic bacteria. Iran. J. Vet. Res. 13: 282-288.

Negi PS and Jayaprakasha GK, 2003. Antioxidant and Antibacterial Activities of Punica granatum Peel Extracts. J. Food Sci. 68: 1473-1477.

Opara L, Al-Ani M and Al-Shuaibi Y, 2009. Physicochemical Properties, Vitamin C Content, and Antimicrobial Properties of Pomegranate Fruit (Punica granatum L.). Food Bioprocess Technol. 2: 315-321.

Panichayupakaranant $\mathrm{P}, \quad$ Tewtrakul $\mathrm{S}$ and Yuenyongsawad S, 2010. Antibacterial, antiinflammatory and anti-allergic activities of standardised pomegranate rind extract. Food Chem. 123: 400-403.

Ross RG, Selvasubramanian $\mathrm{S}$ and Jayasundar S, 2001. Immunomodulatory activity of Punica granatum in rabbits - a preliminary study. J. Ethnopharmacol. 78: 85-87.

$\mathrm{Wu}$ J, Jahncke Ml, Eifert JD, O'keefe SF and Welbaum GE, 2016. Pomegranate peel (Punica granatum L) extract and Chinese gall (Galla chinensis) extract inhibit Vibrio parahaemolyticus and Listeria monocytogenes on cooked shrimp and raw tuna. Food Control. 59: 695-699.

\section{Contribution of Authors}

Tadi M: Conceived idea, designed research methodology, collected data and wrote manuscript Boroujeni HM: Helped in data collection, analysis and manuscript write up Rafieian-Kopaei M: Helped in data collection, analysis and manuscript write up

Sadrabad EK: Supervised research, data analysis and final approval of article 